Thabiea: Journal of Natural Science Teaching
Program Studi Tadris Ilmu Pengetahuan Alam
Institut Agama Islam Negeri Kudus
http://journal.stainkudus.ac.id/index.php/Thabiea
$p$-issn: $2580-8974, e-i s s n: 2655-898 x$

\title{
Pengaruh Pemahaman Konsep Asam Basa terhadap Konsep Hidrolisis Garam Mata Pelajaran Kimia SMA Kelas XI
}

\author{
Ratna Kartika Irawati ${ }^{\mathrm{a}, 1^{*}}$ \\ ${ }^{a}$ Tadris Kimia UIN Antasari Banjarmasin \\ 1ratnakartika@uin-antasari.ac.id*
}

\begin{tabular}{ll}
\hline Informasi artikel & ABSTRAK \\
\hline Kata kunci: & Konsep-konsep dalam ilmu kimia bersifat abstrak dan saling berhubungan, \\
Pemahaman konsep & seperti konsep asam basa dan hidrolisis garam. Hal ini dimungkinkan apabila \\
Asam basa & pemahaman konsep asam basa siswa rendah maka akan sulit memahami \\
Hidrolisis garam & konsep hidrolisis dengan baik. Oleh sebab itu, penelitian ini bertujuan untuk \\
& mengetahui pengaruh pemahaman konsep asam basa terhadap konsep \\
& hidrolisis garam pada mata pelajaran kimia SMA kelas XI MIPA. Penelitian \\
& ini termasuk jenis penelitian korelasi. Teknik pengumpulan data \\
& menggunakan tes pemahaman konsep yang terdiri atas 15 soal pilihan ganda \\
& berpasangan antara konsep asam basa dan hidrolisis garam. Analisis data \\
& menggunakan uji regresi linear. Hasil penelitian menunjukkan bahwa ada \\
& pengaruh pemahaman konsep asam basa terhadap pemahaman konsep \\
hidrolisis garam dengan korelasi tergolong kuat. Sebanyak 51,5\% \\
pemahaman konsep asam basa mempengaruhi pemahaman konsep hidrolisis \\
garam.
\end{tabular}
garam.

Key word:

Understanding concepts

Acid base

Salt hydrolysis

\section{ABSTRACT}

The Influence of Understanding of the Concept of Alkaline Acid on the Concept of Salt Hydrolysis in Chemistry High School Class XI. The concepts in chemistry are abstract and interconnected, such as the concept of acid base and hydrolysis of salt. This is possible if understanding the concept of acid-base students is low so it will be difficult to understand the concept of hydrolysis properly. Therefore, this study aims to determine the effect of the understanding of the acid-base concept on the concept of salt hydrolysis in high school chemistry class XI MIPA subjects. This study includes the type of correlation research. The data collection technique uses concept understanding tests consisting of 15 pairs of MCQs between the concept of acid base and hydrolysis of salt. Data analysis using linear regression test. The results showed that there was an effect of understanding the concept of acid base on the understanding of the concept of salt hydrolysis with a relatively strong correlation. A total of $51.5 \%$ understanding of the concept of acid base affects the understanding of the concept of salt hydrolysis.

Copyright () 2019 Institut Agama Islam Negeri Kudus. All Right Reserved

\section{Pendahuluan}

Menurut Chang (2003), ilmu kimia merupakan salah satu cabang ilmu sains yang mempelajari materi dan perubahannya. Beberapa karakteristik ilmu kimia diantaranya adalah ilmu kimia dibangun dengan metode ilmiah, sebagian besar kajian ilmu kimia bersifat abstrak dan dipelajari dalam urutan tertentu (Sukarna, 2000). Dengan demikian, konsep-konsep yang dikaji dalam ilmu kimia cukup banyak dan kompleks. Kebanyakan konsep ilmu kimia bersifat abstrak dan saling berhubungan satu sama lain. Pernyataan serupa juga diutarakan oleh Vos dan Pilot (1994); Kean dan Middlekamp (1985), bahwa konsepkonsep kimia mempunyai hubungan yang kuat dan saling berurutan.

Salah satu contoh konsep kimia yang saling berhubungan adalah konsep asam basa dan hidrolisis garam. Berdasarkan 
Kurikulum 2013, kedua materi tersebut merupakan materi kimia yang dibelajarkan pada siswa kelas XI MIPA pada semester genap. Materi asam basa dibelajarkan pada siswa pada awal semester, kemudian materi titrasi asam basa, larutan penyangga dan hidrolisis garam. Sebelum mempelajari konsep hidrolisis garam, siswa terlebih dahulu harus memahami konsep asam basa.

Konsep hidrolisis garam tergolong konsep yang sulit bagi siswa menengah atas (Orwat, Bernard, dan Mikuli, 2017). Ada banyak konsep abstrak dan saling berhubungan dengan konsep sebelumnya pada konsep hidrolisis garam. Konsep asam basa merupakan dasar untuk mempelajari konsep hidrolisis garam. Hal ini terlihat pada reaksi garam dengan air pada materi hidrolisis garam. Garam terbentuk dari reaksi asam dan basa. Garam yang terlarut dalam air akan mengalami ionisasi membentuk kation dan anionnya. Kation yang berasal dari basa lemah dan anion yang berasal dari asam lemah dapat mengalami hidrolisis garam. Kekuatan asam basa telah dijelaskan pada teori asam basa Bronsted Lowry. Pada teori asam basa Bronsted Lowry telah dijelaskan tentang hubungan asam basa konjugasi. Sesuai dengan pernyataan Mujiwati (2014), bahwa konsep kekuatan asam basa dan konsep asam basa Bronsted Lowry merupakan konsep dasar yang diperlukan untuk mempelajari konsep hidrolisis garam.

Pemahaman siswa pada konsep yang kompleks, dapat berawal dari pemahaman konsep sederhana. Hal ini berarti apabila konsep sederhana telah dipahami dengan baik, maka siswa akan mudah memahami konsep yang lebih kompleks. Akan tetapi, Nakhleh (1992) menyebutkan bahwa kesulitan siswa mempelajari konsep kimia disebabkan oleh siswa tidak memiliki pemahaman yang tepat pada konsep-konsep awal kimia. Dengan demikian, pemahaman konsep hidrolisis garam akan tercapai dengan baik apabila siswa dapat memahami konsep asam basa dengan baik pula.

Beberapa hasil penelitian menunjukkan bahwa siswa SMA kelas XI MIPA masih mengalami kesalahan konsep hidrolisis garam. Amelia, Marheni, dan Nurbaity (2014) menyebutkan bahwa siswa mengalami kesalahan konsep pada $\mathrm{pH}$ larutan garam yang terhidrolisis dan sifat garam yang terhidrolisis. Sedangkan hasil penelitian yang dilakukan oleh Orwat, Bernard, dan Mikuli (2017) menunjukkan bahwa siswa belum paham tentang proses kesetimbangan, asam basa, struktur materi serta proses pengendapan pada garam. Misal pada larutan magnesium klorida, siswa kesulitan dalam menuliskan reaksi hidrolisis yang tepat. Banyak siswa yang mendiskripsikan bahwa larutan tersebut bersifat netral dan reaksi hidrolisis garam tidak terjadi.

Terjadinya miskonsepsi pada hidrolisis garam dimungkinkan karena pemahaman konsep siswa pada materi asam basa yang kurang bagus. Hasil penelitian tentang pemahaman konsep asam-basa yang telah dilakukan oleh Smith dan Metz (1996), mengatakan bahwa pemahaman siswa terhadap kimia larutan melalui gambaran mikroskopik diperoleh adanya kesalahan pemahaman siswa terhadap konsep larutan asam basa. Hasil penelitian Monangin (1999) menyatakan bahwa hanya $28 \%$ siswa yang dapat memahami konsep asam-basa konjugat. Selain itu juga penelitian yang dilakukan oleh Bradley dan Mosimege (1998) menunjukkan bahwa siswa menganggap semua larutan garam bersifat netral. Kala (2013) juga menyebutkan bahwa siswa kurang memahami grafik hubungan antara asam dan basa lemah. Imaduddin (2018) memaparkan kondisi 
tidak terhubungnya level representasi makroskopik, submikroskopik, dan simbolik dikarenakan pemahaman konsep pada level sebelumnya belum terpenuhi atau komprehensif

Dengan adanya hasil kajian yang menunjukkan terjadi miskonsepsi pada hidrolisis garam dan asam basa maka perlu dilakukan kajian lebih dalam tentang pengaruh pemahaman konsep asam basa terhadap konsep hidrolisis garam pada siswa kelas XI MIPA. Hal ini dimungkinkan pemahaman konsep asam basa mempengaruhi pemahaman konsep hidrolisis siswa.

\section{Metode}

Penelitian ini termasuk penelitian korelasi untuk mengetahui pengaruh pemahaman konsep asam basa terhadap pemahaman konsep hidrolisis garam. Variabel bebas berupa pemahaman konsep asam basa dan variabel terikat berupa pemahaman konsep hidrolisis garam. Populasi penelitian ini adalah siswa kelas XI MIPA SMA Negeri 1 Lawang. Sampel penelitian merupakan siswa kelas XI MIPA 3 SMAN Lawang yang diambil dengan teknik cluster random sampling.

Teknik pengumpulan data menggunakan teknik tes sehingga diperoleh data berupa pemahaman konsep siswa pada materi asam basa dan hidrolisis garam. Instrumen tes dikembangkan untuk memperoleh data yang diperlukan. Tes yang digunakan terdiri atas 15 soal pilihan ganda berpasangan antara konsep asam basa dan hidrolisis garam. Validasi ahli dilakukan pada soal tes pemahaman konsep asam basa dan hidrolisis garam dengan rata-rata sebesar 96,67\%. Hasil uji coba soal tes menunjukkan nilai alpha sebesar 0,728 . Hal ini berarti soal tes termasuk kategori soal yang reliabel dan layak digunakan untuk mengambil data.

Analisis data dilakukan untuk mengetahui pengaruh pemahaman konsep asam basa terhadap pemahaman konsep hidrolisis garam. Data dianalisis menggunakan uji regresi linear dengan bantuan SPSS for Windows 22. Akan tetapi, terlebih dahulu dilakukan uji prasyarat pada data, yaitu uji normalitas dan linearitas

\section{Hasil}

\section{Hasil Tes Pemahaman Konsep Asam Basa}

Hasil tes pemahaman konsep asam basa diperoleh dari jawaban siswa kelas XI MIPA 3 pada soal asam basa. Nilai tertinggi sebesar 93, sedangkan nilai terendah sebesar 47 dengan nilai KKM sebesar 75. Rata-rata hasil pemahaman siswa pada konsep asam basa sebesar 73,34. Berikut sebaran hasil pemahaman konsep siswa pada asam basa.

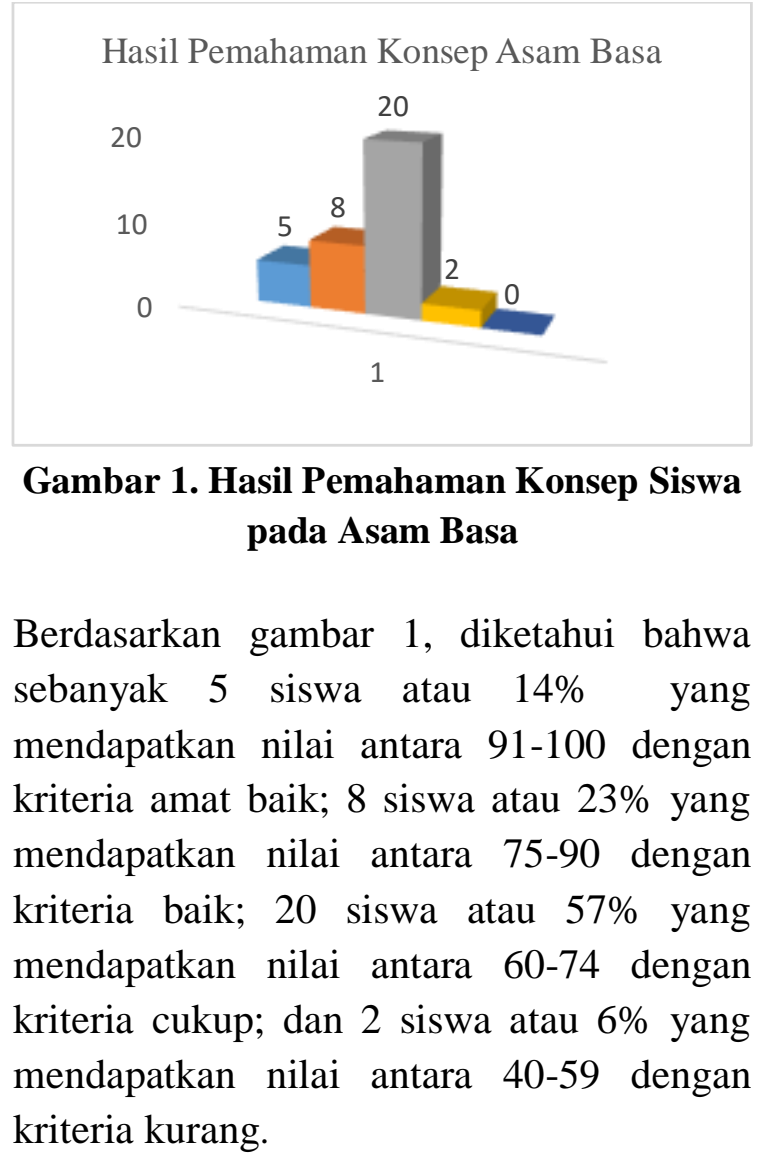




\section{Hasil Tes Pemahaman Konsep Hidrolisis Garam}

Pada hasil pemahaman konsep hidrolisis garam, nilai tertinggi siswa sebesar 100, sedangkan nilai terendah sebesar 47 dengan nilai rata-rata sebesar 74,97. Berikut sebaran hasil pemahaman konsep siswa pada hidrolisis garam.

Hasil Pemahaman Konsep Hidrolisis Garam

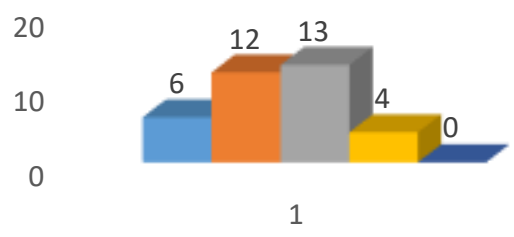

Gambar 2. Hasil Pemahaman Konsep Siswa pada Hidrolisis Garam

Berdasarkan gambar 2, diketahui bahwa sebanyak 6 siswa atau $17 \%$ yang mendapatkan nilai antara 91-100 dengan kriteria amat baik; 12 siswa atau $34 \%$ yang mendapatkan nilai antara 75-90 dengan kriteria baik; 13 siswa atau $37 \%$ yang mendapatkan nilai antara 60-74 dengan kriteria cukup; dan 4 siswa atau $11 \%$ yang mendapatkan nilai antara 40-59 dengan kriteria kurang.

\section{Pengaruh Pemahaman Konsep Asam Basa terhadap Konsep Hidrolisis Garam}

Uji prasyarat dilakukan pada hasil pemahaman konsep asam basa dan hidrolisis garam. uji prasyarat yang dilakukan adalah uji normalitas dan linearitas. Berikut hasil uji prasyarat yang telah dilakukan.

\section{Tabel 1. Hasil Uji Normalitas}

\begin{tabular}{|c|c|c|c|}
\hline Data & $\begin{array}{c}\text { Asymp. } \\
\text { Sig. }\end{array}$ & $\begin{array}{c}\text { Taraf } \\
\text { Sig. }\end{array}$ & Ket. \\
\hline $\begin{array}{c}\text { Pemahaman } \\
\text { Konsep } \\
\text { Asam Basa }\end{array}$ & 0,061 & 0,05 & Distribusi \\
Normal \\
\hline
\end{tabular}

\begin{tabular}{|c|c|c|c|}
\hline Pemahaman & 0,200 & 0,05 & Distribusi \\
Konsep & & & normal \\
Hidrolisis & & & \\
Garam & & & \\
\hline
\end{tabular}

Tabel 2. Hasil Uji Linearitas

\begin{tabular}{|c|c|c|c|}
\hline $\begin{array}{c}\text { Data yang } \\
\text { Diuji }\end{array}$ & Nilai p & $\begin{array}{c}\text { Taraf } \\
\text { Sig. }\end{array}$ & Ket. \\
\hline Uji linearitas & 0,092 & 0,05 & Linear \\
\hline
\end{tabular}

Berdasarkan kedua tabel tersebut, diketahui bahwa data pemahaman konsep asam basa dan hidrolisis garam terdistribusi normal dan linear. Selanjutnya dilakukan uji regresi linear pada data pemahaman konsep asam basa terhadap pemahaman konsep hidrolisis garam. berikut hasil uji regresi linear.

Tabel 3. Hasil Uji Regresi Linear

\begin{tabular}{|c|c|c|c|}
\hline & Pear. Corr. & R.Square & Sig. \\
\hline $\begin{array}{c}\text { Uji } \\
\text { Regresi } \\
\text { Linear }\end{array}$ & 0,717 & 0,515 & 0,000 \\
\hline Ket & Hub. Kuat & $\begin{array}{c}\text { Pengaruh } \\
51,5 \%\end{array}$ & $\begin{array}{c}\mathrm{H}_{\mathrm{o}} \\
\text { ditolak }\end{array}$ \\
\hline
\end{tabular}

Berdasarkan Tabel 3, Pearson Correlation sebesar 0,717 sehingga pemahaman konsep asam basa dan hidrolisis garam tergolong kuat. Sedangkan nilai R. Square sebesar 0,515 sehingga dapat dikatakan 51,5\% pemahaman konsep asam basa mempengaruhi pemahaman konsep hidrolisis garam. Signifikan $0,000<0,05$ sehingga $\mathrm{H}_{\mathrm{o}}$ ditolak sehingga ada pengaruh pemahaman konsep asam basa terhadap pemahaman konsep hidrolisis garam.

\section{Pembahasan}

Rata-rata pemahaman konsep siswa pada materi asam basa sebesar 73,34 dan pada materi hidrolisis garam sebesar 74,97. Hal ini menunjukkan bahwa rata-rata pemahaman konsep siswa pada kedua materi tersebut tergolong baik. Dengan demikian, pembelajaran yang berlangsung pada materi 
asam basa dan hidrolisis garam berjalan dengan baik.

Hasil uji regresi diketahui bahwa ada pengaruh pemahaman konsep asam basa terhadap pemahaman konsep hidrolisis garam. Pemahaman konsep asam basa mempengaruhi pemahaman konsep hidrolisis garam sebesar 51,5\%. Nilai presentasi yang cukup besar membuktikan bahwa konsep asam basa dan hidrolisis garam saling berhubungan. Sebanyak 48,5\% sisanya merupakan faktor lain yang mempengaruhi pemahaman konsep hidrolisi garam. Contohnya, faktor pembelajaran yang dilakukan oleh guru menarik sehingga cukup membuat memahami konsep hidrolisis garam dipahami dengan baik. Selain itu juga faktor kecerdasan masingmasing siswa yang bisa mempengaruhi pemahaman konsep tersebut.

Konsep asam basa dan hidrolisis garam mempunyai hubungan yang kuat. Apabila siswa paham konsep asam basa, maka siswa akan memahami konsep hidrolisis garam dengan baik. Sesuai yang diungkapkan oleh Osborne dan Wittrock (dalam Effendy, 2002) bahwa untuk memahami konsep-konsep yang akan dipelajari, maka siswa harus memahami terlebih dahulu konsep-konsep sebelumnya. Hal ini terlihat pada soal yang diberikan kepada siswa secara berpasangan. Misalkan seperti konsep garam yang mengalami hidrolisis sebagain dan bersifat basa, maka siswa harus memahami konsep asam lemah menurut teori Arrhenius. Selain itu, jika siswa diminta untuk menentukan $\mathrm{pH}$ pada garam $\mathrm{NaF}$ yang terhidrolisis, maka siswa harus memahami konsep asam basa Bronsted Lowry pada asam HF. Jika direaksikan dengan $\mathrm{HS}^{-}$, maka $\mathrm{HF}$ akan memberikan $\mathrm{H}^{+}$kepada $\mathrm{HS}^{-}$membentuk $\mathrm{H}_{2} \mathrm{~S}$ dan $\mathrm{F}^{-}$, sehingga $\mathrm{HF}$ bersifat asam dan $\mathrm{F}^{-}$ bersifat basa kuat. Ketika terbentuk garam
$\mathrm{NaF}$, maka $\mathrm{F}^{-}$akan menarik $\mathrm{H}^{+}$dari $\mathrm{H}_{2} \mathrm{O}$ membentuk HF dan larutan garam tersebut bersifat asam.

Siswa yang bisa memahami konsep konstanta asam sehingga bisa menentukan kekuatan asam sesuai dengan besaran konstanta, maka siswa bisa menentukan $\mathrm{pH}$ garam $\mathrm{CH}_{3} \mathrm{COOK}$ yang mengalami hidrolisis sebagian dalam air. Penjelasan tersebut membuktikan bahwa konsep asam basa merupakan konsep dasar yang harus dipelajari terlebih dahulu sebelum mempelajari materi hidrolisis garam. Hal ini sesuai dengan penelitian yang dilakukan oleh Mufidah (2008) bahwa ada hubungan kuat antara penguasaan konsep asam basa dan hidrolisis garam.

\section{Simpulan}

Pada penelitian ini ditunjukkan bahwa terdapat pengaruh pemahaman konsep asam basa terhadap pemahaman konsep hidrolisis garam dengan korelasi tergolong kuat. Sebanyak 51,5\% pemahaman konsep asam basa mempengaruhi pemahaman konsep hidrolisis garam. Dengan demikian, pengajar kimia diharapkan dapat memperkuat konsep asam basa dan memastikan tidak adanya miskonsepsi yang terjadi pada peserta didik sebelum melanjutkan pembelajaran kimia pada konsep hidrolisis.

\section{Referensi}

Amelia, D., Marheni dan Nurbaity. 2014. Analisis Miskonsepsi Siswa pada Materi Hidrolisis Garam Menggunakan Teknik CRI (Certainty of Response Index) Termodifikasi. Jurnal Riset Pendidikan Kimia. Vol. 4(1): 260-266. 
Bradley, J.D., dan Mosimege, M.D. 1998. Misconceptions in Acids and Bases: A Comparative Study of Student Teachers with Different Chemistry Backgrounds. South African Journal of Chemistry. Vol 51 (3): 137-145.

Chang,R. 2003. Kimia Dasar: KonsepKonsep Inti Jilid 1. Terjemahan oleh Muhamad Abdulkadir, dkk . 2005. Jakarta: Penerbit Erlangga.

Effendy. 2002. Upaya untuk Mengurangi Kesalahan Konsep dalam Pengajaran Kimia dengan Menggunakan Strategi Konflik Kognitif. Media Komunikasi Kimia, 2(6):1-20.

Imaduddin, M. 2018. Analisis Miskonsepsi Submikroskopik Konsep Larutan Pada Calon Guru Kimia. Edu Sains: Jurnal Pendidikan Sains \& Matematika, 6(2): 1-12.

Kala, Nesli., Yaman, Fatma., dan Ayas, Alipasa. 2013. The Effectiveness of Predict-ObserveExplain Technique in Probing Students Understanding About Acid-Base Chemistry: A Case for The Concepts of $\mathrm{pH}, \mathrm{pOH}$, and Strength. International Journal of Science and Mathematics Education. 11(2): 555-574.

Kean, E. dan Middlecamp, C. 1985. Panduan Belajar Kimia Dasar. Jakarta: PT Gramedia.

Monangin, R.R. 1999. Kerancuan Pemahaman Konsep Sebagai Akibat Pengajaran Konsep Asam-Basa Arrhenius dan Konsep Asam-Basa Bronsted-Lowry. Tesis tidak diterbitkan. Malang: Program Pascasarjana Institut Keguruan dan Ilmu Pendidikan Malang.

Mufidah, L. 2008. Pengaruh Penguasaan Konsep Asam Basa terhadap Tingkat Penguasaan Konsep Hidrolisis Garam yang Diajarkan dengan Model Learning Cycle 5 Fase. Skripsi tidak diterbitkan. Malang: Jurusan Pendidikan Kimia Universitas Negeri Malang.

Mujiwati, N. 2014. Identifikasi Pemahaman Konsep Materi Hidrolisis Garam Siswa Kelas XI IPA SMA Negeri 2 Mejayan Kabupaten Madiun Tahun Ajaran 2013/2014. Skripsi tidak diterbitkan. Malang: Jurusan Pendidikan Kimia Universitas Negeri Malang.

Nakhleh, M.B. 1992. Why Some Students Don't Learn Chemistry. Journal of Chemical Education, 69 (3): 191-195.

Orwat, K., Bernard, P., Mikuli, A.M. 2017. Alternative Conceptions of Common Salt Hydrolysis among Upper Secondary School Students. Journal of Baltic Science Education. Vol 16 (1): 64-76.

Smith, K.J. dan Metz, P.A. 1996. A Grinard Reaction to Dye For, Evaluating Student Understanding of Solution Chemistry through Microscopic Representations. Journal of Chemical Education, 73(3): 233-235.

Sukarna, I.M. 2000. Karakteristik Ilmu Kimia dan Keterkaitannya Dengan Pembelajaran di Tingkat SMU. Yogyakarta: Departemen Pendidikan Nasional Universitas Negeri Yogyakarta Fakultas Matematika dan Ilmu Pengetahuan Alam.

Vos,W. dan Pilot,A. 2001. Acids and Bases in Layers: The Stratal Structure of an Ancient Topic. Journal of Chemical Education. 78(2): 494-498. 